\title{
The Benchmarking of Innovation and Entrepreneurship Education
}

\author{
Mei Chiao Lai \\ Fuzhou University of International Studies and Trade \\ Fuzhou, China 350202
}

\author{
$\mathrm{Xu}$ Gao \\ Fuzhou University of International Studies and Trade \\ Fuzhou, China 350202
}

\author{
Wu Der Tsay \\ Fuzhou University of International Studies and Trade \\ Fuzhou, China 350202
}

\begin{abstract}
Undergraduate colleges and universities are facing new opportunities for innovation and entrepreneurship education. In order to highlight the teaching characteristics and students' employment advantage, the purpose of the paper is to explore the amplification of benchmarking through benchmarking the excellent experience in Taiwan and the literature review method. According to the explore results provide some suggestions for the implementation of benchmarking, which would help the development of innovation and entrepreneurship education and its strategic decision making.
\end{abstract}

Keywords-innovation and entrepreneurship education; benchmark learning; Taiwan

\section{INTRODUCTION}

The State Council issued the Opinions on Energetic Promotion of the Several Policies for Encouraging People to Start Their Own Businesses and Make Innovations in June 2015. The document about both entrepreneurship and innovation pointed out that China needs to put forward thirty measures on over ten aspects including innovation-driven and development of innovative enterprises etc. The Prime Minister of the State Council, Li Keqiang pointed out that innovation not only is the support for China to realize the "double medium-to-high" but also is the support for cultivation of new advantages for international competitiveness. The policies of central government on innovation development result from the coordination of the education of undergraduate colleges with the national important policies in teaching, which leads to one of the research motivations.

Based on the industrial development requirements for Fujian free trade test zone, the new requirements of "excellent industries" put forward by the General Secretary Xi Jinping during his visiting in Fujian in 2014, complete the support platform with the innovation driving development, promote the production-teaching-research combination and grip the innovation lifeline to inject new energy for the industrial development. From December 2014, the State Council approved to establish the China (Fujian) Free Trade
Test Zone and formulated the Industrial Development Planning for China (Fujian) Free Trade Test Zone (20152019) till the Several Opinions on Deepening the Technology System Reform and Accelerating the Innovation System Construction of the People's Government of Fujian Province and Fujian Provincial Party Committee of the Communist Party of China, the policies and requirements for industrial development and innovation of local Fujian Provincial Government lead to the second research motivation.

Only acting blindly can't make the undergraduate colleges highlight the teaching features of entrepreneurship and innovation as well as the competitive advantages which need to refer to and emulate the experience of others. Remedy the shortcomings through imitation and learning so as to further develop own features of entrepreneurship and innovation education which lead to the third research motivation.

The research purposes of this paper according to those mentioned above are as follows:

- Understand the current development status of entrepreneurship education in domestic colleges;

- Discuss the advanced experience of benchmark learning objectives;

- Suggest matters for the references of entrepreneurship education for applied economics.

\section{LITERATURE DISCUSSION}

The combing of domestic and foreign literatures related to innovation and entrepreneurship education, benchmark learning is described as follows.

\section{A. Innovation and Entrepreneurship Education}

Reviewing the history of innovation and entrepreneurship education, at the earliest in December 1989, the United Nations Educational Scientific and Cultural Organization has launched the "International Seminar Facing the Education in 20th Century" in Beijing and officially put forward the 
concept of "Entrepreneurship Education". At the same time, the regional offices in Asian-Pacific region of the United Nations Educational Scientific and Cultural Organization launched the "education unified reform project on promoting the entrepreneurship abilities of teenagers" and nine countries including China and Japan etc. participated in this project. At the end of 1989, the project planning conference was launched in Bangkok, Thailand. The mid-project seminar was launched in Tokyo, Japan in January 1991 and the project final assessment was launched in Bangkok, Thailand again in November 1991.

Recently, on June 17, 2016, the United Nations Educational Scientific and Cultural Organization and other eight institutions of the colleges in various countries in the world signed the Propose in Hangzhou in Hangzhou University which aims at constructing the idea and vision of global innovation and entrepreneurship education, exploring the development approaches for international entrepreneurship and innovation education in the new period and leading the sustainable development of global economy and society. The Propose in Hangzhou reached to agreements on the cooperative cultivation of talents for innovation and entrepreneurship, construction of global interactive platform for innovation and entrepreneurship, construction of course teaching system for entrepreneurship education, cultivation of high-quality teaching staff for entrepreneurship education and development of international quality standards for entrepreneurship education etc.

Comb the literatures related to the innovation-driven development and learn that based on the policies of innovation and entrepreneurship, the domestic scholars focus on the issues such as the theoretical origin, scientific connotation, value and significance, realistic routine and evaluation index etc. for innovation-driven development strategies, conduct broad discussion and deep research on the development of innovation and entrepreneurship from different theoretical perspectives, provide with certain theoretical supports and obtain abundant achievements. However, the opinions of scholars and experts show that there are still shortcomings needing to be enhanced such as, Zhang Lizhen and Qin Zhilong (2015) pointed out that the innovation-driven development strategies should enhance the empirical study and micro examination. An Tongliang, Wang Wenyi and Wang Lei (2012) conducted plenty of primary researches on self-dependent innovation but were still unable to decide which is right on many issues. $\mathrm{Li}$ Dongxing (2013) pointed out that there still existed many difficulties in the implementation of innovation-driven development strategies of our country. Therefore, implementing the innovation and entrepreneurship education on the aspect of talents supply becomes the important issue.

\section{B. Benchmark Learning Methods}

The benchmarking method was firstly created by the American Xerox Corporation in 1979 and together with business reengineering and strategic alliances was called the three major management methods in 1990s by the western management academia. The benchmark learning theory was originated from the management method globally acknowledged- the benchmarking with the core of becoming or surpassing the first-rate objectives through referring to the successful methods or other improvement measures of the first-rate objectives. The benchmarking has achieved remarkable actual effects in the business circles and has been generally acknowledged. This advanced management method gradually permeates to various industries including the teaching in colleges.

The selection of benchmark objectives, based on the benchmark learning referring to the enterprise models proposed by Lv Jinzhen (1996) and Chen Zuoming (2000), should classify the benchmark learning types according to different learning objectives which are as show in: "Table I".

TABLE I. ClassiFy THE BENCHMARK LEARNING TyPES ACCORDING TO DIFFERENT LEARNING OBJECTIVES

\begin{tabular}{|c|c|c|c|}
\hline Type & Definition & Advantages & Disadvantages \\
\hline $\begin{array}{c}\text { Internal } \\
\text { benchmark } \\
\text { learning }\end{array}$ & $\begin{array}{l}\text { Learn from } \\
\text { that belong to } \\
\text { the same } \\
\text { enterprises } \\
\text { while not the } \\
\text { same } \\
\text { departments } \\
\text { or operating } \\
\text { units }\end{array}$ & $\begin{array}{l}\text { 1. Easy on material } \\
\text { collection. } \\
\text { 2. Relatively easy } \\
\text { obtaining of assistance } \\
\text { from the other party. } \\
\text { 3. With the same type, } \\
\text { learning obstacle will } \\
\text { be lower. }\end{array}$ & $\begin{array}{l}\text { 1. All belong to the } \\
\text { same type, so it is } \\
\text { difficult to } \\
\text { producing } \\
\text { breakthrough } \\
\text { thoughts. } \\
\text { 2. Large limitation. }\end{array}$ \\
\hline $\begin{array}{c}\text { External } \\
\text { benchmark } \\
\text { learning }\end{array}$ & $\begin{array}{l}\text { Learn from } \\
\text { the } \\
\text { enterprises } \\
\text { with same } \\
\text { industry, } \\
\text { same } \\
\text { customer } \\
\text { group and in } \\
\text { competitive } \\
\text { relations }\end{array}$ & $\begin{array}{l}\text { 1. Similar operation } \\
\text { modes, measures, } \\
\text { technologies, financial } \\
\text { information etc can } \\
\text { ensure the quantization } \\
\text { comparison based on } \\
\text { same foothold. } \\
\text { 2. Arouse the fighting } \\
\text { will of the same } \\
\text { industry to fight with } \\
\text { external competitors } \\
\text { with comparability. }\end{array}$ & $\begin{array}{l}\text { 1. It will be not } \\
\text { easy to obtain the } \\
\text { face-to-face } \\
\text { communication } \\
\text { with the } \\
\text { competitors due to } \\
\text { the adversarial } \\
\text { relationship. } \\
\text { 2. When searching } \\
\text { information, the } \\
\text { doubts of moral } \\
\text { controversy will } \\
\text { easily happen. }\end{array}$ \\
\hline $\begin{array}{c}\text { Functional } \\
\text { (general) } \\
\text { benchmark } \\
\text { learning }\end{array}$ & $\begin{array}{l}\text { Learn from } \\
\text { the } \\
\text { departments } \\
\text { in different } \\
\text { industries } \\
\text { while being } \\
\text { identified as } \\
\text { possessing } \\
\text { the optimum } \\
\text { operation } \\
\text { efficiency on } \\
\text { certain } \\
\text { functions. }\end{array}$ & $\begin{array}{l}\text { 1. It will not involve } \\
\text { the sensitive issues } \\
\text { like trade secrets and } \\
\text { will be easy to obtain } \\
\text { the information and } \\
\text { assistance from the } \\
\text { other party due to the } \\
\text { different industries. } \\
\text { 2. The creative } \\
\text { thoughts will be easily } \\
\text { produced due to } \\
\text { different industries. }\end{array}$ & $\begin{array}{l}\text { 1. The differences } \\
\text { in industrial } \\
\text { features and culture } \\
\text { are too much which } \\
\text { will be difficult to } \\
\text { be transplanted. } \\
\text { 2. The learning } \\
\text { period will be } \\
\text { relatively long and } \\
\text { the obstruction will } \\
\text { be relatively large. }\end{array}$ \\
\hline
\end{tabular}

Data source: revised and collected from, (1). Benchmark learning- referring to enterprise models (p.32), Translated by Lv Jinzhen, 1996, Taipei: Tianxia Culture (2). Study on the Implementation of Benchmarking of Enterprises for Promotion of the Operation Performance- A Case Study of Changgu Construction Company (Page 16-22), Chen Mingzuo, 2000, master's thesis of business management department in National Sun Yat-sen University, Gaoxiong.

Integrating with the table above to compare, the advantages and disadvantages are as follow:

When conducting the benchmark learning from the outstanding enterprises in the same industry, due to the same 
customer group and similar operation modes, the measures, technologies and financial information etc. can be quantitatively compared based on the same standpoint and the transplant of processes is also feasible (Camp, 1989). And due to the routine competiveness in the same industry, most of information has been collected and the comparison on differences can be made immediately and the fighting wills of same industry can also be inspired. While the biggest issue lie in the competitive relation of both parties and the collection of information has moral controversy (Spendolini, 1992) and the face-to-face communication with competitor can't be obtained easily. Another measure is to learn from the single operation mode of the enterprises of different industries with specialized similar operating processes (Came, 1989). Because this method is to learn from the enterprises of different industries, it will not involve the sensitive issues such as trade secrets and will be easy to obtain the information and assistance of the other party. Also, due to the different industries and the distinctively different concept and measures, it will be easy to cause impact to the industries in enclosed environment and further cause the generating of innovative ideas (Watson, 1993) and stimulate the enterprises to conduct reform on operation processes. However, due to the too many differences in industrial features and culture of both parties, the obstruction on transplant will be relatively large (Camp, 1989).

\section{Applied Economics}

The setting of majors of domestic Bachelor degree or above is in accordance with the three levels of "discipline category", "discipline genera (first-level discipline)" and "major" (second-level discipline). Hereinto, the economics is subdivided into two first-level disciplines including theoretical economics and applied economics. And the second-level disciplines subdivided under the applied economics are national economics, regional economics, fiscal science (including: taxation), finances (including: insurance), industrial economics, international trade, labor economics, statistics, quantitative economics and national defense economics etc. The applied economics is the discipline to study the theories, operation regulations and management in various relevant fields of economic activities which possesses the features of close combination with theory and practice, strong applicability and direct services for economic construction.

The economics disciplines and majors transform the economic theories with general fundamentality owned to relevant fields into the media and bridge of various economic policies, economic management system and realistic society productive forces, gradually become the principles and theoretical basis for the governments of various countries to formulate the economic development strategies and have important position and functions in the entire economics, economic management and scientific technology fields. Thus, we can see the importance of teaching and talents cultivation for applied economics.

\section{Practice Promotion of BenChMARK LEARNing}

The processes of benchmark learning include benchmark learning orientation, locking learning objectives, collection of materials, analysis and giving learning measures and adopting reform activities. The following are separately explained in cases.

\section{A. Formulate the Benchmark Learning Orientation}

There are three opportunities for the innovation and entrepreneurship education of China. The first is the college education in the new era which centers on the Internet plus strategy and the issue of sharing economy to cultivate the brands of innovation and entrepreneurship talents, aim at three directions of transition such as innovative scientific research, innovative talents and innovative public benefit and insist on resource integration, innovative intelligence enlightenment and complementary of advantages. The second is that the new society needs the innovation and entrepreneurship abilities with new energy and new vitality. The colleges coordinate to construct the ecological environment for innovation and entrepreneurship, construct the effective entrepreneurship training system with "multiple forms, multiple channels and broad coverage and strengthen the more deep cooperation among the government, educational institutions and enterprises. The third is to develop the teaching reform exploration, integrate the innovation and entrepreneurship education into the talent training and practically improve the innovative spirits, entrepreneurship ideas and innovation and entrepreneurship abilities of college students so as to lead the entrepreneurship with innovation, lead the employment with entrepreneurship and cultivate the new force to "encourage the people to start their own business and make innovations".

There are also three challenges faced by the innovation and entrepreneurship education of China. The first is that the unit of innovation and entrepreneurship education includes educational environment, entrepreneurship enlightenment, business promotion, entrepreneurial management and entrepreneurial strategies and other units. How to integrate every unit into the courses and case practice is the first challenge. The second is that the methods for innovation and entrepreneurship education are crucial to the entrepreneurship educational connotation for college students, the core ideas of entrepreneurship education for college students, the features of the entrepreneurship education for college students, exploration of the entrepreneurship educational methods for college students and the practice on entrepreneurship educational measures and methods of colleges. How to teach the students to make skillful and good use of the methods for innovation and entrepreneurship is the second challenge. The third is that the innovation and entrepreneurship need the integrated education reform of colleges. It only can be possible to show the innovation and entrepreneurship education achievements of colleges through inspiring the creativity and enthusiasm for innovation and entrepreneurship with the guidance of teachers on the teaching contents and methods. And how to construct the exchange platform of the innovation and entrepreneurship project of college students and the social 
investment and closely combine the competition achievement transformation and the industry-universityresearch to promote the innovation and entrepreneurship of college graduates with higher quality is the third challenge.

Therefore, the processes of benchmark learning should formulate and determine the benchmark learning orientation of one's own and determine what to learn from the benchmark, who is the user of benchmark learning information and their demands so as to define the subject of benchmark learning. Once knowing the subject and demands of benchmark learning, the needed resources such as time, capital and personnel etc. can be determined and obtained so as to successful accomplish the investigation of benchmark learning.

\section{B. Select the Objective of Benchmark Learning}

Under general conditions, the benchmark management can be divided into three kinds including strategic, operational and international benchmark management. This paper adopts the operational benchmarking and aim at the detailed operation of innovation and entrepreneurship education links of undergraduate colleges to find and achieve the favorable operation modes.

If needing to conduct the benchmark learning, firstly comb the relevant literatures, award records obtained from the institutions or departments of politics, industry, university and research, best practice identified by the medium to become the best operation or organize the learning paradigm objectives. There are generally three kinds of objectives to be conducted. The most convenient measure is to learn nearby from the department with excellent performance in the enterprise because the materials can be easily obtained and there are no issues of different enterprise cultures and the effects can be achieved immediately (Bendell, Boulter \& Goodstadt, 1998). However, due to the same enterprise, under the congenital conditions with same culture and same industry, the breakthrough thoughts are hard to be produced (Spendolini, 1992).

\section{Material Collection}

Collect the teaching materials and methods which are crucial to the innovation and entrepreneurship education for applied economics including how can the unit of innovation and entrepreneurship education be integrated into the specialized courses, entrepreneurship educational connotations, core ideas of students entrepreneurship education, features of the entrepreneurship education for college students, exploration of the measures for innovation and entrepreneurship and the practice of entrepreneurship methods for colleges etc; and how to construct the exchange platform of the innovation and entrepreneurship project of college students and the social investment and closely combine the competition achievement transformation and the industry-university-research to promote the entrepreneurship and employment of college graduates with higher quality which are all the contents of the collected materials. Generally speaking, according to the complexity for obtaining the data, the measures for material collection are nothing more than files, publications or media, questionnaire survey, telephone interview and interview/ live interview. As for what measures should be adopted, this mainly depends on the limitation of time and data, experience, information collection ideas and the demands of final users and other factors (Spendolini, 1992).

\section{Organize the Teams and Formulate Learning Measures}

Form the benchmark learning teams. Most of the benchmark learning is conducted in teams to select, train and manage the benchmark learning teams. The members in teams should possess the clear roles and responsibilities and are assisted with project management tools. After the teams has determined the cooperative relationship with the benchmark partners, collect and analyze related information according to the assessment items and methods set by both parties and put forward the proposals for actions to ensure that every participant to clear their tasks and the team also should formulate the important phased objectives.

\section{E. Adopt the Reform Actions}

Integrated with the above procedures, all are to prepare for this phase so as to achieve the benchmark learning objectives, which are to learn, improve, change current status and grow. If this phase is lacked and just stops at material collection, analysis and providing with written reports and lay aside and neglect, this activity can be deemed as a failure Only when the organization starts the actions and implement the reform to achieve the improvement of performance, can the value of benchmark learning be manifested (Camp, 1989; Spendolini, 1992).

\section{BENCHMARK THE COLLEGES IN TAIWAN AS LEARNING MODEL}

The people with entrepreneurship in Taiwan are increasing year by year. The Global Entrepreneurship Monitor reports in 2014 pointed out that the ratio of working population participated in the newly started business in Taiwan is $8.49 \%$, increased by $0.37 \%$ compared with that of 2013. While in recent years, the innovation and entrepreneurship platforms of universities and colleges in Taiwan have also been successively established and the courses related to entrepreneurship even increased by 7 times in recent 10 years with the total number of near 800 kinds. The American research institutions in Washington, the Global Entrepreneurship Spirit and Development Institution (GEDI) reviewed the global entrepreneurship development. The report issued in November 2015 pointed out that Taiwan ranked top six among the international 130 units in entrepreneurship, ranked top 2 in Asia. The innovation and entrepreneurship education of Taiwan is worthy of benchmarking.

\section{A. Core Process on Campus of Case Colleges}

Take a college in Taiwan as an example, to help the students possess the entrepreneurship experience in advance or event successful entrepreneurship, the key points of core processes for implementation of benchmarking cases include five aspects which separately are innovation and entrepreneurship education, entrepreneurship laws and 
intellectual property rights, entrepreneurship cases and hedging information, entrepreneurship reality and market assessment as well as entrepreneurship award and financial capital. The key point explanations are as shown in "Table II".

TABLE II. KEY POINTS OF CORE PROCESSES FOR IMPLEMENTATION OF BENCHMARKING CASES

\begin{tabular}{|c|c|c|c|}
\hline $\mathbf{S} / \mathbf{N}$ & Key point & Contents & Implementation methods \\
\hline \multirow[t]{2}{*}{1} & \multirow[t]{2}{*}{$\begin{array}{l}\text { Innovation and } \\
\text { entrepreneurship } \\
\text { education }\end{array}$} & $\begin{array}{l}\text { 1. Research journals for } \\
\text { Entrepreneurship } \\
\text { education }\end{array}$ & $\begin{array}{l}\text { Connect to the research website for innovation management. The journal is published } 4 \text { times } \\
\text { annually. People can refer to the researches related to entrepreneurship and can be inspired } \\
\text { with the multiple ideas about entrepreneurship }\end{array}$ \\
\hline & & $\begin{array}{l}\text { Entrepreneurship } \\
\text { lectures }\end{array}$ & $\begin{array}{l}\text { Link to the Digital Video-On-Demand System to inquire the school entrepreneurship lectures } \\
\text { and entrepreneurship aptitude test; link to the National E-Job to conduct the functional } \\
\text { exploration investigation and also can link to the employment functional platforms of colleges } \\
\text { and the scale of learning and reading strategies for college students to conduct the vocational } \\
\text { interest exploration and test what occupation is suitable for themselves. }\end{array}$ \\
\hline 2 & $\begin{array}{l}\text { Laws and } \\
\text { intellectual } \\
\text { property rights }\end{array}$ & law and regulation & $\begin{array}{l}\text { Patent and intellectual rights, industrial and commercial registration, employee rights and } \\
\text { benefits, entrepreneurship cases and other related resources and websites }\end{array}$ \\
\hline \multirow[t]{2}{*}{3} & \multirow[t]{2}{*}{$\begin{array}{l}\text { Entrepreneurship } \\
\text { cases and hedging } \\
\text { information }\end{array}$} & \multirow[t]{2}{*}{$\begin{array}{l}\text { 1. Case catalogue } \\
2 . \quad \text { Information } \\
\text { enlightenment }\end{array}$} & $\begin{array}{l}\text { Case catalogue: provide the contents related to the entrepreneurship cases for references of the } \\
\text { future entrepreneurship of students } \\
\text { Other education references: link to the Entrepreneurship and Oneiromancy Website and } \\
\text { Website at the medium and small scale enterprises in economic section to find the } \\
\text { entrepreneurship tendency }\end{array}$ \\
\hline & & & Quote the abundant information in the industry and avoid the possible risks \\
\hline \multirow[t]{3}{*}{4} & \multirow[t]{3}{*}{$\begin{array}{l}\text { Entrepreneurship } \\
\text { reality and market } \\
\text { assessment }\end{array}$} & 1. Start an enterprise & $\begin{array}{l}\text { There are abundant teaching resources. The editor uses the situation guidance method to lead } \\
\text { the visitors to enter into the entrepreneurship reality-analyze the possible problems and } \\
\text { pertinently provide with solutions }\end{array}$ \\
\hline & & 2. Business model & $\begin{array}{l}\text { Help the students to construct the enterprise ideas and use the method of case study to transmit } \\
\text { this idea to the entrepreneurial business concept }\end{array}$ \\
\hline & & 3. Market assessment & $\begin{array}{l}\text { Establish an enterprise and use the swot to analyze the internal and external advantages and } \\
\text { disadvantages. }\end{array}$ \\
\hline \multirow[t]{2}{*}{5} & \multirow[t]{2}{*}{$\begin{array}{l}\text { Entrepreneurship } \\
\text { award and } \\
\text { financial capital }\end{array}$} & Entrepreneurship award & $\begin{array}{l}\text { The students combine the technologies learnt from the school and the entrepreneurship ideas } \\
\text { and provide this idea to the Ministry of Education to refer to, review, approval and accepting } \\
\text { the coaching from incubation unit, and then they can obtain the subsidy amount of the } \\
\text { Ministry of Education. }\end{array}$ \\
\hline & & $\begin{array}{l}\text { Capital demands and the } \\
\text { profit plans }\end{array}$ & $\begin{array}{l}\text { The enterprises must take the issues like how to distribute the salary, pension, insurance } \\
\text { expenses and advertising expense etc and other related incidental expenses and expenses on } \\
\text { equipment and the successful evaluation, profit forecast etc into consideration. The } \\
\text { entrepreneurship prospectus: including the functions of prospectus, summary and writing } \\
\text { examples and the template downloading can be accessed to inquire and review. }\end{array}$ \\
\hline
\end{tabular}

\section{B. Off-campus Resources and Performance Assessment of} Case Colleges

Except for investing the expenditures to organize the benchmark learning of innovation and entrepreneurship, the colleges in Taiwan also can strive for the governmental subsidy on college innovation and entrepreneurship education. The subsidy measures in Taiwan are explained as follow.

The colleges in Taiwan can apply to the local government for the budget subsidy on the [central demonstration school plans on innovation and entrepreneurship] under the conditions that the colleges should set up the organizations integrated with research and development and the incubation function for the specific responsibility on the industry-academy cooperation; students applying the entrepreneurship simulation platform for college students, students who are recommended by the school to participate in the practice module of entrepreneurship education have completed the registration on the entrepreneurship simulation platform for college students; people in organizations can apply for the optimized entrepreneurship teams while for the non-individual, the subsidy courses have no specific units and the subsidy amount will subject to the subsidy amount on the announcement with the annual maximum limit and the maximum course amount limit.

The governmental units will also relatively require the benefit evaluation after the implementation of subsidy to include six perspectives: organization and management, overall operation, industry connection, management performance and the perspective covering the school review project on courses and entrepreneurship guidance; the performance evaluation for innovation courses is divided into four perspectives: course planning, course implementation and administrative cooperation; the entrepreneurship teams will evaluate the these perspectives of industry and practice connection as well as the setting performance of courses.

\section{CONCLUSION}

For the entrepreneurship education development of applied economics in domestic colleges, under the policies on innovation and entrepreneurship, governments from the State Council to the local Fujian Provincial Government actively promote the development and education policies on the aspect of talent supply and the Ministry of Education also 
coordinates with the policies to promote the practical transformation of undergraduate colleges. Therefore, the innovation and entrepreneurship education for applied economics is for the differentiation and breakthrough of development.

The paper suggests taking the colleges in Taiwan as the learning model, because among the 130 countries and districts, Taiwan ranks top 6 for entrepreneurship development. Conduct the benchmark learning of the core processes in the case colleges of Taiwan and the advanced experiences so as to accelerate the development of innovation and entrepreneurship education and highlight the features and advantages.

\section{ACKNOWLEDGEMENT}

It should express the deepest gratitude to Fuzhou University of International Studies and Trade with serial number JF2017021 and name of "2017 school-level key construction courses--Logistics service marketing".

\section{REFERENCES}

[1] Zhang Lizhen, Qin Zhilong. "Innovation-Driven Development Strategies", Journal of Sichuan University of Science \& Engineering(Social Sciences Edition), 2015, 30 Vol. the fourth issue

[2] Li Dongxing, 2013, "Study on Innovation-Driven Development Strategies", Journal of the Central Institute of Socialism

[3] An Tongliang, Wang Wenyi, Wang Lei, "Literature Review on the Study on Self-Dependent Innovation in China", Academia Bimestrie, 2012, 02 issue

[4] Dai Changjun, Li Jinming: Benchmarking, Tianjin: Tianjin People's Publishing House, Edition in 1996.

[5] Chen Zuoming, Study on the Implementation of Benchmarking of Enterprises for Promotion of Operation Performance- A Case Study of Changgu Construction Company (Page16-22), master's thesis of business management department in National Sun Yat-sen University, 2000.

[6] Lin Genglong, Case Study on Benchmark Learning Promoting Organization Reform, master's thesis of business management department in National Sun Yat-sen University, 2000.

[7] Translated by Lv Jinzhen, Benchmark learning- referring to enterprise models (p.32), Taipei: Tianxia Culture, 1996.

[8] Bendell, T., Boulter, L. \& Goodstadt, P. (1998), "Benchmarking for Competitive Advantage, 2nd Edition," Great Britain: Pitman Publishing.

[9] Camp, R.C. (1989a). "Benchmarking: The Search for Best Practices That Lead to Superior Performance, Part I". Quality Progress, January:61-69.

[10] Camp, R.C. (1989b). "Benchmarking: The Search for Best Practices That Lead to Superior Performance, Part II". Quality Progress, February:70-75.

[11] Camp, R.C. (1989c). "Benchmarking: The Search for Best Practices That Lead to Superior Performance, Part IIII". Quality Progress, March:76-82.

[12] Camp, R.C.(1989d). "Benchmarking: The Search for Industry Best Practices That Lead to Superior Performance". Milwaukee, Wisconsin: American Society for Quality Control (ASQC)

[13] Camp, R.C.(1989e). "Benchmarking: The Search for Best Practices That Lead to Superior Performance, Part IV". Quality Progress, April:62-69.

[14] Watson, Gregory H.(1993). Strategic Benchmarking: How to Rate Your Company's Performance against the World's Best. New York: John Wiley\&Sons, Ins. 